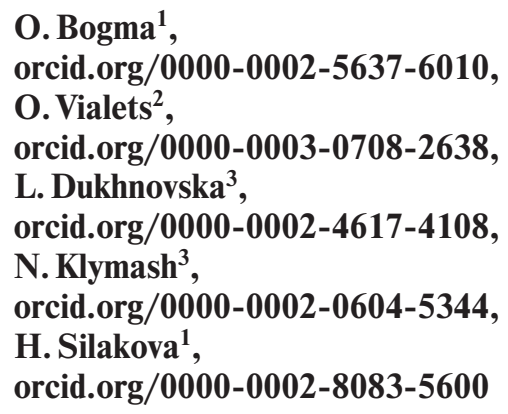

1 - Kyiv National University of Trade and Economics, Kyiv, Ukraine; e-mail: o.bogma@knute.edu.ua

2 - Institute of Postgraduate Education of National University of Food Technologies, Kyiv, Ukraine

3 - National University of Food Technologies, Kyiv, Ukraine

\title{
AUTOMATED CONTROL SYSTEM AS A TOOL FOR ENSURING FINANCIAL AND ECONOMIC SECURITY OF THE ENTERPRISE
}

Purpose. To develop a comprehensive mathematical model of the automated system of preparation and decision-making to ensure effective control of financial and economic security of the enterprise.

Methodology. The study used a set of general and special methods of cognition: regular observation and comparative analysis, content analysis, logical generalization, quantitative and qualitative comparison, macro- and micro-prudential analysis, scientific abstraction and systematization, mathematical formalization.

Findings. It is established that in modern conditions effective control of financial and economic security of the enterprise needs new information tools. A complex methodical approach to creation of the automated system of support and decision-making for the control of financial and economic safety of the enterprise is offered. A mathematical model is proposed to identify threats and predict their consequences, identify areas where increased control and monitoring of indicators is required. Algorithms of blocks of the automated system for an estimation of level of safety and threshold values of safety intervals are offered.

Originality. In the course of research, a complex mathematical model of the system of preparation and decision-making for maintenance of the effective control of financial and economic safety of the enterprise is developed. Unlike the existing ones, the complex mathematical model includes original algorithms: those of the limits of the interval of the guaranteed level of security for an individual enterprise; for assessing the level of financial and economic security of the enterprise under the conditions of dynamic changes in the level of threats, levels of security and methodological approaches to determining the basic indicators. A mathematical apparatus for isolating the impact of risks on time series of dependencies of key indicators has also been developed.

Practical value. The results of the study can be used to create automated information systems and support and decision-making systems with the function of controlling the financial and economic security of the enterprise. They can also be widely used for practical needs by enterprise management and scientists in improving the methodology of automated control, improving the effectiveness of countering threats. The forecasts of the activity of seaports in Ukraine presented in this article can be directly used by practitioners and scientists. For ease of use, analytical equations in the form of polynomials are provided.

Keywords: mathematical model; prognostication; information system; safety interval, financial and economic security

Introduction. Effective work and the very existence of the enterprise in modern conditions are impossible without a proper level of financial and economic security of the enterprise (FESE). The key to this is effective and reliable control tools. Organizing such control without the current comprehensive assessment of large arrays of diverse information (big data), such as the state of system resources, analysis of volatility of financial and economic performance of the enterprise and a homogeneous group of enterprises or industries for changes in external and internal factors, system indicators, etc. without proper analytical and information support is impossible. Control and analysis of financial and economic activities (FEA) must be comprehensive, threat detection requires maximum automation. Therefore, the task is to form a proper mathematical basis for analytics and build a structure of the system of preparation and decision-making (SPDM) that will accumulate the necessary information, store it, process it automatically and report threatening trends with certain changes in the main controlled indicators.

Literature review. In the world practice, the S\&P Dow Jones and MSCI (Morgan Stanley Capital International World Index) indices are used to assess the company's place in the financial market. Higher values of such indices mean more investment, and trends in their change indicate the security of financial and economic activity of the enterprise (FEAE). Unfortunately, the level of development of the stock market in Ukraine does not allow using these tools.

(C) Bogma O., Vialets O., Dukhnovska L., Klymash N., Silakova H., 2020
The problem of the FEA is global, so works by both Ukrainian scientists and scientists from other countries are devoted to studying it. Zwolak, in particular, points out that FES issues are important for all enterprises - both large and small ones [1], Olejarz, et al. [2], Rekova, et al. [3], Burkaltseva, et al. [4]. Blakyta and Ganushchak [5], Franchuk, et al. [6], Nitsenko, et al. [7, 8] analyze security parameters; Biliomistniy, et al. [9] classify external and internal threats, their impact on security, Haber, et al. [10] suggested method for determining the level of security and its forecasting model. Davydenko studied aspects of the genesis of the problem of economic and financial security of the enterprise [11]. Britchenko, et al. [12], Danyliuk, et al. [13], Metelenko [14] highlighted the sectoral aspects and features of FES control. Ramskyi and Solonko [15] analyzed in detail the mechanism of financial security formation. Some aspects of this study were used in developing the structure proposed for consideration by SPDM. An interesting approach to the formation of the FES mechanism is the work by Shtangret [16], devoted to the issue of crisis management. Also useful for building the SPDM structure was Rushchyshyn's study [17], which formed a connection between the FES and strategic planning. Numerous scientific publications are devoted to the methods of mathematical modeling of FEAE, parameters and indices for assessing its safety. This is thoroughly done in $[16,17]$.

Unfortunately, there is a lack of scientific work on mathematical models of automated control systems FESE for the Ukrainian market.

Unsolved aspects of the problem. The scientific works by the above-mentioned scientists are a solid theoretical basis for 
solving various aspects and approaches to the organization of FESE control. Unfortunately, the issues of organization of control in the conditions of excessive amounts of primary data and rapid changes in external challenges and internal security threats were left out of consideration. In such conditions, effective control without special information systems is impossible. These systems must work in the presence of algorithms created for them and mathematical models that underlie these algorithms. Therefore, the question of creating complex mathematical models of automated information systems to identify threats to the FES, automate the assessment of their impact and develop measures to neutralize these threats remains open.

The purpose is to develop a comprehensive mathematical model of the automated system of preparation and decisionmaking to ensure effective control of FESE.

Methods. During the study, a set of general and special methods of cognition was used: regular observation and comparative analysis for the selection of effective tools in forming the structure of SPDM: content analysis for an objective comprehensive assessment of mathematical tools to ensure the control of FESE; logical generalization for the formation of the mathematical core of the control information system; quantitative and qualitative comparison to formulate a generalized algorithmic approach to estimating the limits of the guaranteed safety interval for an individual enterprise; macroand micro-prudential analysis for comprehensive qualitative assessment of threats and comparative analysis of trends in their change; scientific abstraction and systematization to justify the choice of mathematical apparatus; mathematical formalization to build a mathematical model for identifying threats and forecasting their consequences, in order to identify areas of increased control and monitoring of indicators of these areas and maneuver resources to neutralize the threat.

The method of content analysis of approaches to assessing the indicators of threats, intervals of safe operation of the enterprise and other theoretical aspects allowed forming a comprehensive algorithmic approach to creating an automated control system FESE. The use of the method of logical generalization allowed us to analyze the theoretical basis and identify the elements required for the synthesis of a single algorithm of such an automated system. A comprehensive methodological approach was used to conduct the study, combining methods of prudential analysis, quantitative and qualitative comparison, scientific abstraction and systematization and mathematical formalization.

The use of such a methodological approach allows automating the process of control of FESE, conducting certain stages of tracking the occurrence of threats, the size of the danger, identifying the area of the enterprise being in danger in the automatic mode, warning management of the threat in real time. Automation of control will significantly increase its efficiency.

Results. For efficient use of resources and possible modification of SPDM, the application of an algorithm organized on a block basis is proposed.

The results of application of the block of methods of quantitative and qualitative comparison and prudential analysis. During the study it was found out that with the purpose to increase the efficiency of quantitative and qualitative comparison, in particular, to analyze the aggregate performance of a homogeneous group of enterprises, current assessment of volatility of financial and economic performance and assessment of volatility of FES indicators, other stages of the algorithm to change safety level this method, the algorithms that realize it, must be applied at all times. For a comprehensive qualitative assessment of FEAE threats, it is advisable to use prudential analysis. We propose to use macro- and micro-prudential analysis as the only integrated approach in the monitoring and control of FESE. And macroprudential analysis should be conducted not for the industry as a whole, but for a homogeneous group of enterprises in order to identify threats common to the group and the results of regulatory measures to reduce threats and neutralize their consequences. Unification of approaches to the formation of measures for common threats is useful for a particular enterprise. It is proposed to compare the time trends of a homogeneous group of enterprises, identified by applying macro-prudential analysis and the time trend of a particular enterprise, which is the result of micro-prudential analysis of harmonics that distinguish trends of the enterprise and a homogeneous group of enterprises. Thus, the only prudential integrated approach to trend analysis allows identifying the socalled "individual" threats to the enterprise. Sequential analysis of time changes in the difference of trends and their amplitudes allows estimating the magnitude of the impact of the threat and predicting the consequences of the threat over time.

This requires ongoing prudential analysis of security levels and potential threats. An alarming sign for the management of the enterprise is the reaching of an integrated indicator the level of FESE limits of the safety interval. Thus, the use of a block of methods of quantitative and qualitative comparison and prudential analysis allowed formulating an algorithmic approach to determine the limits of the interval of guaranteed safety and analysis of changes in trends of indicators for a comprehensive assessment of threats.

The results of the application of the block of methods of scientific abstraction and systematization. This block is designed to substantiate the choice of mathematical apparatus, building an effective SPDM algorithm. Its use provides an approach to identifying the effects of threats and managing countermeasures under the condition of using resources and maneuvering their reserves.

The resources of the system include not only tangible but also intangible assets. Resources are inventories; available equipment; technologies used in organizational and production activities; information resources; staff, and others. The outcome of the proposed resource maneuver to reduce the impact of threats or their consequences should be analyzed.

The use of a specialized unit for modeling and identifying threats, forecasting their consequences requires significant SPDM resources and an effective mode of operation of the analytical group with the information system. The work of analysts will identify threats and detect areas that require increased control using the methodology modified according to circumstances. Forecasting threats and their level will allow management to counter threats timely, organize a maneuver of financial, human, material and other resources.

The first stage of application of the complex methodical approach became the formation of algorithm of identification of threat influences and the mechanism of management of risk counteraction. The implementation of continuous monitoring has the main task of identifying the threat, even at the outset, bypassing the stage of its identification and determination of its genesis. The next steps are to identify the threat, minimize its impact and consequences. To identify internal threats, it is proposed to use their detection of growing trends: lack of competitive advantage, increased overhead costs, dependence on external financing, growth of receivables and payables, lack of working capital, reduced liquidity of own assets and so on. Standard algorithms use the resources of the enterprise information system - accounting databases and accounting records.

Not all external threats can be identified at once, and in order to prepare tools to reduce their impact duly, it is necessary to rely on information on the volume, direction and identified sphere of activity at risk. To do this, it is proposed to assess the limits of the safety interval by analyzing the trends of a group of homogeneous enterprises, using the appropriate algorithm. One of the purposes of using this algorithm is to confirm or refute the assumption that there is a connection between the structural correlation of a homogeneous group of enterprises and their level of FES. This assumption is not unfounded as for companies belonging to a homogeneous group, 
the impact of external threats and response to them must be identical. Therefore, the basis of the proposed approach is to identify quantitative indicators of the limits of the safety interval under the indicative approach. For this forecasting we propose to use an optimistic and pessimistic version of the indicators of future periods of the enterprise, similar to one or a group of planned indicators of enterprise development, calculated using the trends of aggregate results of a homogeneous group of enterprises. The limits of indicators outline the following intervals of enterprise activity at the appropriate level of threats: normal (acceptable level of danger), unstable, critical and the interval of crisis beginning. There are different approaches to basic indicators, such as the use of coefficients of autonomy or financing, the provision of their own working capital, the maneuverability of equity. Scientific sources offer options for approaches to the formation of an integrated indicator of FES: to use the characteristics of the property status of the enterprise (coefficients of constancy of assets, depreciation of fixed assets, mobility of assets); liquidity characteristics (current liquidity ratios and absolute liquidity); characteristics of financial stability and sustainability etc. (hereinafter calculations based on the Ukrainian Sea Ports Authority, http:// www.uspa.gov.ua/pokazniki-roboti).

In the general case, it is more appropriate to use a block approach: blocks of budget, credit, banking, financial and technological activities and so on. However, the choice of basic indicators should be the result of the analysis of a homogeneous group of enterprises and a specific individual enterprise. For example, there are cases when such an indicator, at least in the first stage of the analysis, may be the result of the enterprise activity. A detailed comprehensive analysis certainly requires the use of the broadest group of indicators.

During the study, it was found out that the method for determining the basic indicators of internal and external security cannot be unified. It needs to be corrected, as well as the assessment of the volatility of the limits of security intervals for the analysis of financial and economic condition, as the level of financial and economic security is not static. Therefore, an algorithm for assessing the level of financial and economic security of the enterprise with dynamic changes in the level of threats, security levels and improvement of methodological approaches to determining basic indicators (Fig. 1) was proposed.

The results of the application of the block of methods of mathematical formalization. One of the problematic issues in the formation of an automated information system (SPDM) with the control function of FESE is the adaptation of security management to uncertainty conditions. Uncertainty in the input information leads to uncertainty in the results of the analysis, which can cause ignoring the threat warning which is a forecast with a low level of reliability. One of the uncertainties

\begin{tabular}{|c|c|}
\hline \multirow{2}{*}{$\begin{array}{c}\text { Modification of the } \\
\text { methodololgy for } \\
\text { determining the basic } \\
\text { indicator of internal security }\end{array}$} & $\begin{array}{l}\text { Improving the methodology } \\
\text { for determining the basic } \\
\text { indicator of external security }\end{array}$ \\
\hline & 5 \\
\hline & Assessment of the state of \\
\hline $\begin{array}{l}\text { Estimation of threshold } \\
\text { values of safety intervals }\end{array}$ & $\begin{array}{l}\text { dynamic equilibrium of the } \\
\text { security level of the } \\
\text { enternrise as an element }\end{array}$ \\
\hline & of a homogeneous group \\
\hline Estimation of volatility & \\
\hline $\begin{array}{l}\text { of threshold values of safety } \\
\text { intervals for the analysis } \\
\text { of a financial and } \\
\text { economic condition }\end{array}$ & $\begin{array}{l}\text { Assessment of the level offi } \\
\text { ffinancial and economic } \\
\text { security of the enterprise } \\
\text { for a specific time interval }\end{array}$ \\
\hline
\end{tabular}

Fig. 1. Algorithm for assessing the level of financial and economic security of the enterprise with dynamic changes in the level of threats and security levels is the algorithm of forming an integrated indicator of the enterprise, in accordance with the value of which, according to the recommendations of scientists, it is desirable to conduct an assessment [18]. Uncertainty of a separate component of the integrated indicator, obviously, leads to uncertainty of the integrated indicator. Cherep [19] considers some options for the formation of an integrated indicator of the level of financial and economic security of the enterprise. The approach proposed in scientific works for the formation of the SPDM algorithm has been modified. To do this, an integrated indicator $(S)$ is formed in an additive way from a set $n$ ) of indicators

$$
S=\sum_{i=1}^{n} S_{i},
$$

where $S_{i}$ is comprehensive indicators of profitability assessment; solvency assessments; business activity; financial stability; property status. These complex indicators by components are calculated as

$$
S_{i}=\sum_{j=1}^{m} \frac{S_{i j}}{m \cdot N_{j}},
$$

where $m$ is the number of components of each complex indicator; $N_{j}$ is the normative indicator of each component of the complex indicator.

It is not rational to consider complex indicators as those having equal weight when calculating the integrated indicator. Therefore, the formula for the integrated indicator is modified

$$
S=\sum_{i=1}^{n} A_{i} S_{i},
$$

where $A_{i}$ is the weighing coefficients of the impact of each complex indicator on the integrated indicator. Accordingly, formula (1) is represented as

$$
S_{i}=\sum_{j=1}^{m} B_{j} \frac{S_{i j}}{N_{j}},
$$

where $B_{j}$ means weighing coefficients of influence of each component of a complex indicator on its volume.

Weighing coefficients $A_{i}, B_{j}$ are proposed to be determined by the factor analysis. This allows avoiding uncertainty in the genesis of a particular component if its share of influence on the integrated indicator, as well as its volume and direction of the vector of influence is known. We used the Box-Jenkins model as the basis of the mathematical model [20]. According to this model, it is known that the trend of the time series is considered as a result of the influence of systematic and random components. The random component is called "white noise". We have proposed the filtering of "white noise" and the selection of non-random components. Obviously, the regular component is influenced by the identified purely regular factors. The presence of irregular factors, which are comparable in impact with regular, may be due to: seasonal impact; undetected regular components; impact of risk. Each of these reasons is important for the formation of relevant forecasts and accurate assessment of the impact of risks.

Regular observation and comparative analysis of trends allows us to identify the seasonal component. Standard algorithms are used for this purpose. The presence of undetected regular components can be checked by detecting a correlation between the $i^{\text {th }}$ and $(i-k)^{\text {th }}$ element of the series. Because the effect is manifested every $k$ time intervals, it is called "season$\mathrm{al}$, of order $k$ ". But the very selection of the impact of risks requires a combination of mathematical apparatus and the work of analysts. To begin with, separate harmonics are programmatically allocated in "white noise". Harmonics larger in amplitude are filtered. The rates and vectors of their changes are analyzed. When the rate increases and the influence of harmonics negatively changes the trend of the systematic compo- 
nent, this is a signal of danger and requires expert intervention. To analyze the regular effect of several parameters, we proposed a modification of the time series model from scalar to vector form. This is done in order to maintain the stationarity of the series under the influence of $z$ parameters and to avoid multicollinearity of factors.

$$
\overrightarrow{X_{\tau}}=\delta+\sum_{i=1}^{z} \overrightarrow{\varphi_{i}} \cdot \overrightarrow{X_{\tau-i}}+\sum_{i=1}^{z} \overrightarrow{\varepsilon_{i}},
$$

where $\delta$ is constant; $\overrightarrow{\varphi_{i}} \cdot \overrightarrow{X_{\tau-i}}$ is a vector product of two vectors $\left(\overrightarrow{\varphi_{i}}\right.$ and $\left.\overrightarrow{X_{\tau-i}}\right) ; \overrightarrow{\varphi_{i}}$ is the vector of autoregression parameters; $\tau$ is time line; $\overrightarrow{X_{\tau-i}}$ is the vector for time interval $(\tau-i) ; \overrightarrow{\varepsilon_{i}}$ is the vector of influences of harmonics of "white noise". Equation (5) analytically simulates the time series on the response surface in space dimension $(z+1)$.

To use the moving average approach, we use a modified equation

$$
\overrightarrow{X_{\tau}}=\mu+\sum_{i=1}^{z} \overrightarrow{\varepsilon_{i}}-\sum_{i=1}^{z} \overrightarrow{\theta_{i}} * \overrightarrow{\varepsilon_{\tau-i}}
$$

where $\mu$ is constant; $\overrightarrow{\theta_{i}}$ is moving average parameters vector.

Equation (4) analytically models the superposition on the influence of the current value of random harmonics and the influence of a linear combination of random harmonics in previous periods.

Because, programmatically it is possible not only to catch so-called "colored harmonics" in "white noise" $\overrightarrow{\varepsilon_{i}}$ but also to find out their changes for all sets $z$, it is possible to analyze the correlation of "colored harmonics" with changes in the parameters in the vector $\vec{\theta}_{i}$, i. e. to connect the desired harmonics with the parameters of the moving average. This simplifies the identification of the causes of "colored harmonics". But, even without their identification, it is possible to assess their impact on the outcome of the trend change for future forecasts. Then the only problem is the reason for their occurrence, because without finding out the cause, it is impossible to reliably assume that their trend will remain unchanged, and they will not cease to operate for the forecast time.

For example, an analysis of the activities of a homogeneous group of seaports in Ukraine and the port of Odesa is conducted. Information on the components of the integrated indicator of FES, in this case, is a trade secret, so as an indicator of FES the volume of processed goods was used. On the one hand, the advantage of this approach is the adequacy and availability of information on the whole homogeneous group of enterprises and individual ports. On the other hand, the volume of processed cargo is a real indicator of both technological and logistical efficiency of port services, the efficiency of its management, and an indicator of the impact of external and internal threats.

Since the seaports of Ukraine are universal in terms of types of cargo, it is advisable to assess not only according to the total volume of cargo but also for individual types of cargo, which may determine a certain specialization of a particular port.

$$
\begin{gathered}
y=-65.188 \cdot x^{5}+1571.7 \cdot x^{4}-13452 \cdot x^{3}+50122 \cdot x^{2}- \\
-82468 \cdot x+195612 .
\end{gathered}
$$

Taking into account the risks, the forecasting of the activity of the specified group of enterprises for the future period was carried out. Forecasting was based on two options - optimistic and pessimistic. The optimistic one (Figs. 2-5) reaches the upper limit of the relative error interval for this period of time, the pessimistic one - respectively, the lower limit. For dry and bulk cargo handled by a homogeneous group of enterprises (Fig. 3)

The trend line of the volumes of dry cargo handled by Odesa seaport (Fig. 4)

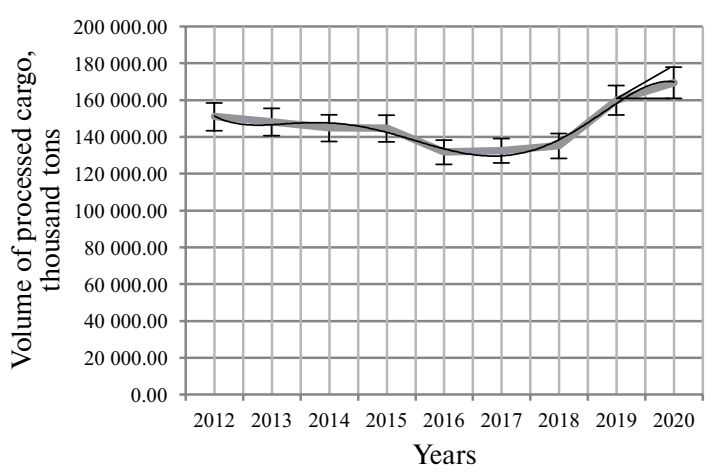

Fig. 2. Forecast of volumes of cargo handled by seaports of Ukraine, million tons

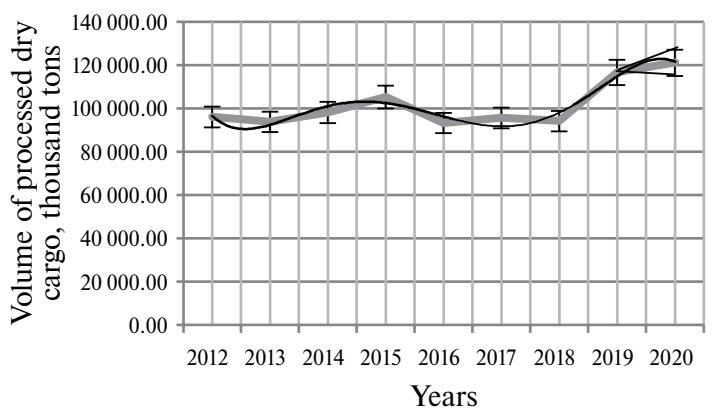

Fig. 3. Forecast of volumes of dry cargo handled by seaports of Ukraine, million tons

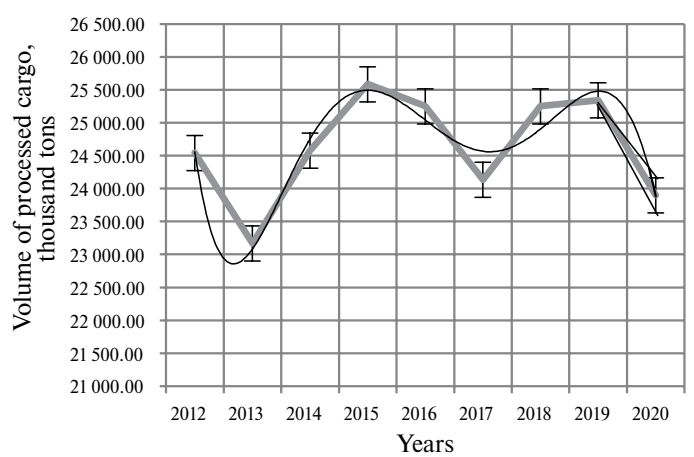

Fig. 4. Forecast of volumes of cargo handled by Odesa seaport, million tons

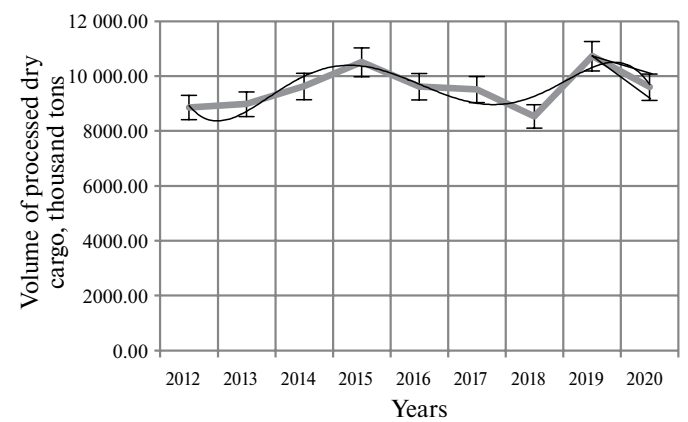

Fig. 5. Forecast of volumes of dry cargo handled by the Odessa seaport, million tons

$$
\begin{gathered}
y=-9.4809 \cdot x^{5}+236.48 \cdot x^{4}-2146.6 \cdot x^{3}+8562.3 \cdot x^{2}- \\
-14120 \cdot x+16401 .
\end{gathered}
$$

The trend assessment for the group of homogeneous enterprises was compared with the trend assessment for a separate seaport of Odesa. These trends are not identical, which indicates that the port of Odesa has not only risks common to 
other ports, but also individual risks. The comparison of trends indicates a high probability of significant individual risk for the Port of Odesa during the current year, which will lead to a decrease in bulk cargo, which, in turn, will reduce the total volume of cargo handled by Odesa Seaport in 2020.

Conclusions. To qualitatively increase the effectiveness of FESE control, a comprehensive mathematical model of the decision-making system is proposed. For this mathematical model, original algorithms have been developed, in particular, the algorithm of threshold values of the interval of the guaranteed level of security for an individual enterprise; algorithm for assessing the level of FESE under the condition of dynamic changes in the level of threats, security levels and even changes in methodological approaches to the definition of basic indicators.

A mathematical apparatus for isolating the impact of risks on the time series of dependencies of the main indicators has been developed. For this purpose, in systematic components of the specified dependencies the influence of "white noise" is specified. In this noise separate harmonics - "colored noise" - are specified by programming methods. The impact of colored noise is analyzed and harmonics larger in amplitude are filtered. Then the rates and vectors of their changes are analyzed. When the pace increases and the influence of harmonics negatively changes the trend of the systematic component, it is a signal of danger and requires management intervention. To analyze the regular effect of several parameters, we proposed a modification of the time series model from scalar to vector form. This is done in order to maintain the stationarity of the series under the influence of $z$ parameters and to avoid multicollinearity of factors.

The study revealed that neither the security status, nor the threshold values of security intervals, nor the method for determining the basic indicators of internal and external security can be established once and for all. They need constant correction and, if necessary, modification.

Using the information of the Association of Seaports of Ukraine, an analysis of the activities of seaports was conducted. Obviously, such a group of enterprises meets the definition of "homogeneous group". Taking into account the risks, the forecasting of the activity of the specified group of enterprises for the future period was carried out. Forecasting was based on two options - optimistic and pessimistic. For this period of time, the pessimistic option reaches the lower limit of the range of relative errors. The line of a trend of volumes of cargoes processed by group of the homogeneous enterprises is formed. The trend of processed cargo volumes is also formed for the port of Odesa. Their difference indicates the presence of individual threats to the port of Odesa, which will affect the overall performance of the port.

\section{References.}

1. Zwolak, J. (2017). The financial security of small- and medium-sized enterprises in Poland. Ekonomski Pregled, 68(4), 399-412.

2. Olejarz, T., Nitsenko, V., Chukurna, O., \& Mykhailova, M. (2018). Evaluation of factors influencing labour performance of machine-building enterprises in mining industry. Naukovyi Visnyk Natsionalnoho Hirnychoho Universytetu, (1), 154-162. https://doi.org/10.29202/nvngu/2018-1/2.

3. Rekova, N., Dolozina, I., Nitsenko, V., Zaitsev, Y., \& Zamlynskyi, V. (2018). Budgetary revenue structure at central level of public administration in the federal countries. Administratie si Management Public, 30, 37-50. https://doi.org/10.24818/ amp/2018.30-03.

4. Burkaltseva, D., Borsch, L., Blazhevich, O., Frolova, E., \& Labonin, I. (2017). Financial and economic security of business as a primary element in the economic system. Revista: Espacios, 38(33), 3-20.

5. Blakyta, G., \& Ganushchak, T. (2018). Enterprise financial security as a component of the economic security of the state.
Investment Management and Financial Innovations, 15(2), 248256.

6. Franchuk, V., Omelchuk, O., Melnyk, S., \& Mykytyuk, O. (2020). Identification of the ways of counteraction of the treats to the financial security of the high-tech enterprises. Verslas teorija ir praktika, 21(1), 1-9. https://doi.org/10.3846/ btp. 2020.11215 .

7. Nitsenko, V., Kotenko, S., Hanzhurenko, I., Mardani, A., Stashkevych, I., \& Karakai, M. (2020). Mathematical Modeling of Multimodal Transportation Risks, (pp. 439-447). In: Ghazali R., Nawi N., Deris M., Abawajy J. (Eds.) Recent Advances on Soft Computing and Data Mining. SCDM 2020. Advances in Intelligent Systems and Computing, 978. Springer, Cham. https://doi.org/10.1007/978-3-030-36056-6 4.

8. Nitsenko, V., Kotenko, S., Hanzhurenko, I., \& Ingram, K. L. (2020). Determination of Weight Coefficients for Stochastic and Fuzzy Risks for Multimodal Transportation. Journal of Physics: Conference Series, 1529, 032007. https://doi. org/10.1088/1742-6596/1529/3/032007.

9. Biliomistniy, O., Bilomistna, I., \& Galushko, Y. (2017). Influence external and internal factors to financial security of enterprise. Financial and credit activity: problems of theory and practice, 1(22), 105-111. https://doi.org/10.18371/fcaptp. v1i22.109935.

10. Haber, J., Bukhtiarova, A., Chorna, S., \& Lastremska, O. (2018). Forecasting the level of financial security of the country on the example of Ukraine. Investment Management and Financial Innovations, 15(3), 304-317. https://doi. org/10.21511/imfi.15(3).2018.25.

11. Davydenko, N. (2015). Genesis of enterprise financial security. Economic Processes Management: International Scientific E-Journal, (2). Retrieved from https://essuir.sumdu.edu.ua/ bitstream-download/123456789/40296/1/Davydenko.pdf. 12. Britchenko, I., Bohomolova, N., Kravchenko, O., \& Pinchuk, S. (2018). Assessment of the determinants of financial security of railways in Ukraine. Financial and credit activity: Problems of Theory and Practice, 4(27), 270-281. https://doi. org/10.18371/fcaptp.v4i27.154109.

13. Danyliuk, V., Riepina, I., Shafalyuk, O., Kovylina, M., \& Nitsenko, V. (2020). Functional and investment strategies of technical development of enterprises. Naukovyi Visnyk Natsionalnoho Hirnychoho Universytetu, (3), 115-121. https://doi. org/10.33271/nvngu/2020-3/115.

14. Metelenko, N. (2018). Conceptual model for assessing financial safety in the system of economic security of industrial enterprise. Management and entrepreneurship: Trends of Development, 4(06), 95-110. https://doi.org/10.26661/25221566/2018-4/06-11.

15. Ramskyi, A., \& Solonko, A. (2018). Mechanism of formation of financial security of an enterprise. European Scientific Journal of Economic and Financial Innovation European Association of Economists, 1, 14-20. https://doi.org/10.32750/20180102 .

16. Shtangret, A., \& Sylkin, O. (2018). Anti-crisis mechanism of countering the impact of external and internal threats of the financial security of machine-building enterprises. Social Legal Studios, 2, 169-176.

17. Rushchyshyn, N., Nikonenko, U., \& Kostak, Z. (2017). Formation of financial security of the enterprise based on strategic planning. Baltic Journal of Economic Studies, 3, 231-233. https://doi.org/10.30525/2256-0742/2017-3-4-231-237.

18. Nitsenko, V., Nyenno, I., Kryukova, I., Kalyna, T., \& Plotnikova, M. (2017). Business model for a sea commercial port as a way to reach sustainable development goals. Journal of Security and Sustainability Issues, 7(1), 155-166. https://doi. org/10.9770/issi.2017.6.4(13).

19. Cherep, A., \& Khudoliei, L. (2017). Improvement of Methodological approaches for assessment of financial and economic safety of machine building enterprises. Theoretical and Practical Aspects of Economics and Intellectual Property, 16, 355-361. 
20. Chukurna, O., Nitsenko, V., Kralia, V., Sahachko, Y., Morkunas, M., \& Volkov, A. (2019). Modelling and Managing the Effect of Transferring the Dynamics of Exchange Rates on Prices of Machine-Building Enterprises in Ukraine. Polish Journal of Management Studies, 19(1), 117-129. https://doi. org/10.17512/pjms.2019.19.1.09.

\section{Автоматизована система контролю як інструмент забезпечення фінансово- економічної безпеки підприємства}

\author{
О. С. Богма ${ }^{1}$ О. В. В'ялещь ${ }^{2}$, Л. М. Духновська ${ }^{3}$, \\ Н. І. Климаш ${ }^{3}$, Г. В. Сілакова ${ }^{1}$
}

1 - Київський національний торговельно-економічний університет, м. Київ, Україна; e-mail: o.bogma@knute.edu.ua 2 - Інститут післядипломної освіти Національного університету харчових технологій, м. Київ, Україна

3 - Національний університет харчових технологій, м. Київ, Україна

Мета. Розробити комплексну математичну модель автоматизованої системи підготовки та прийняття рішень щодо забезпечення ефективного контролю ФЕБП.

Методика. У ході дослідження використана сукупність загальних і спеціальних методів пізнання: регулярного спостереження й порівняльного аналізу, контент-аналізу, логічного узагальнення, кількісного та якісного порівняння, макро- й мікро-пруденційного аналізу, наукового абстрагування й систематизації, математичної формалізації.

Результати. Встановлено, що в сучасних умовах ефективний контроль фінансово-економічної безпеки підприємства потребує нових інформаційних інструментів. Запропоновано комплексний методичний підхід до створення автоматизованої системи підтримки та прийняття рішень для контролю фінансово-економічної безпеки підприємства. Запропонована математична модель для виявлення загроз і прогнозування їх наслідків, виявлення сфер, де потрібен підвищений контроль і моніторинг показників. Запропоновані алгоритми блоків автоматизованої системи для оцінки рівня безпеки й порогових значень інтервалів безпеки.

Наукова новизна. У ході дослідження розроблена комплексна математична модель системи підготовки та прийняття рішень для забезпечення ефективного контролю фінансово-економічної безпеки підприємства. На відміну від існуючих, комплексна математична модель включає в себе оригінальні алгоритми: меж інтервалу гарантованого рівня безпеки для окремого підприємства; оцінки рівня фінансово-економічної безпеки підприємства за умови динамічних змін рівня загроз, рівнів безпеки та методичних підходів до визначення базових індикаторів. Розроблено також математичний апарат виокремлення впливу ризиків на часових рядах залежностей основних показників.

Практична значимість. Результати дослідження можуть бути використані для створення автоматизованих інформаційних систем і систем підтримки та прийняття рішень 3 функцією контролю фінансово-економічної безпеки підприємства. Вони також можуть бути широко використані для практичних потреб менеджментом підприємств і науковцями при вдосконаленні методики проведення автоматизованого контролю, підвищення ефективності протистояння загрозам. Наведені прогнози діяльності морських портів України можуть бути безпосередньо використані практиками й науковцями. Для зручності використання надані аналітичні рівняння у вигляді поліномів.

Ключові слова: математична модель, прогнозування, інформаційна система, інтервал безпеки, фінансово-економічна безпека

\section{Автоматизированная система контроля как инструмент обеспечения финансово- экономической безопасности предприятия}

\author{
Е.С. Богма ${ }^{1}$, О. В. Вялеи ${ }^{2}$, Л. Н. Духновская ${ }^{3}$, \\ Н. И. Климаш ${ }^{3}$, А. В. Силакова ${ }^{1}$
}

1 - Киевский национальный торгово-экономический университет, г. Киев, Украина; e-mail: o.bogma@knute.edu.ua 2 - Институт последипломного образования Национального университета пищевых технологий, г. Киев, Украина 3 - Национальный университет пищевых технологий, г. Киев, Украина

Цель. Разработать комплексную математическую модель автоматизированной системы подготовки и принятия решений по обеспечению эффективного контроля финансово-экономической безопасности предприятия.

Методика. В ходе исследования использованы совокупность общих и специальных методов познания: регулярного наблюдения и сравнительного анализа, контент-анализа, логического обобщения, количественного и качественного сравнения, макро- и микро-пруденциального анализа, научного абстрагирования и систематизации, математической формализации.

Результаты. Установлено, что в современных условиях эффективный контроль финансово-экономической безопасности предприятия требует новых информационных инструментов. Предложен комплексный методический подход к созданию автоматизированной системы поддержки и принятия решений для контроля финансово-экономической безопасности предприятия. Предложена математическая модель для выявления угроз и прогнозирования их последствий, выявление сфер, где требуется повышенный контроль и мониторинг показателей. Предложены алгоритмы блоков автоматизированной системы для оценки уровня безопасности и пороговых значений интервалов безопасности.

Научная новизна. В ходе исследования разработана комплексная математическая модель системы подготовки и принятия решений для обеспечения эффективного контроля финансово-экономической безопасности предприятия. В отличие от существующих, комплексная математическая модель включает в себя оригинальные алгоритмы: границ интервала гарантированного уровня безопасности для отдельного предприятия; оценки уровня финансово-экономической безопасности предприятия при динамических изменениях уровня угроз, уровней безопасности и методических подходов к определению базовых индикаторов. Разработан также математический аппарат выделения влияния рисков на временных рядах зависимостей основных показателей.

Практическая значимость. Результаты исследования могут быть использованы для создания автоматизированных информационных систем и систем поддержки и принятия решений с функцией контроля финансово-экономической безопасности предприятия. Они также могут быть широко использованы для практических нужд менеджментом предприятий и учеными при совершенствовании методики проведения автоматизированного контроля, повышения эффективности противостояния угрозам. Приведенные прогнозы деятельности морских портов Украины могут быть непосредственно использованы практиками и учеными. Для удобства использования предоставлены аналитические уравнения в виде полиномов.

Ключевые слова: математическая модель, прогнозирование, информационная система, интервал безопасности, финансово-экономическая безопасность

Recommended for publication by I. Yu. Shtuler, Doctor of Economic Sciences. The manuscript was submitted 08.06.20. 